\title{
BEYOND MAINSTREAM LABOUR MARKET THEORY AND PRECARITY: TOWARDS AN ALTERNATIVE TO THE NEOLIBERAL MODEL OF DEVELOPMENT
}

\author{
David Neilson \\ Societies and Cultures, Waikato University
}

\begin{abstract}
This paper contextualises contemporary precarity within a mid-range focus on labour market segmentation that takes Marx's long-range theory of the 'relative surplus population' as its point of departure. It also briefly outlines an alternative 'model of development' which could address the increasing precarity of a growing proportion of the world's population. It first sets out a critical analysis of core elements of mainstream accounts of the labour market, which is a point of comparison in the later sections. The paper ends with an exploratory discussion about how neoMarxist analysis can supplement Keynesianism, and how both need to be re-focused more clearly on the need to design a post-neoliberal model of development.
\end{abstract}

\section{Introduction}

In contrast to mainstream labour market theory that focuses on exchange relations, this paper brings production relations into the foreground; and it moves beyond the mainstream assumption of freely exchanging individuals in the market to examine the socially segmented structure of the labouring population under capitalism. Marx's theory of the 'relative surplus population' grounds this alternative approach. His argument is that dynamically increasing productivity within capitalist social relations of production structures historically evolving patterns of labour market segmentation that drive over the long term a growing relative surplus population (Marx 1867; Neilson and Stubbs 2011).

Mid-range models of capitalism, beyond both Marx's long run theory and the mainstream's short range analysis, are central for understanding recent and contemporary national labour market forms. Here, particular attention is paid to capitalism's contemporary mid-range regulatory framework, defined as the 'neoliberal model of development' (Neilson 2012; Neilson and Stubbs, forthcoming). Finally, the progressive character of the post-WWII Keynes-inspired Fordist model of development provides lessons for thinking about an alternative beyond the present neoliberal model of development that could make possible more progressive labour market arrangements.

A critical discussion of neoclassical and Keynesian theories of the labour market in the first section focuses the second section's account of Marx's theory. In the context of the contemporary neoliberal model of development, discussion moves to an examination of mid-range labour market themes. Then, with reference to the seminal and progressive nature of the Keynes- 
inspired post WWII model of development, discussion turns to consider key elements of a blueprint for a progressive post- neoliberal model of development.

\section{Mainstream Accounts of the Labour Market}

In the neo-classical account of naturalised and universalised free markets, employment levels are treated as a function of labour's price that is grounded in the interaction of supply and demand side factors. On the demand side, the employing agents of capital are treated as 'pricetakers' who can viably employ individuals up to the price equivalent to their 'marginal productivity'. This concept focuses on the natural hierarchy of skill levels, rather than labour processes. At the bottom margin of the labour market where marginal productivity is lower; wage levels must also be lower for people to be employable. In general, and perhaps the central neoclassical assumption, as the price of labour decreases, the availability of jobs increases.

Consistent with neoclassical theory's tendency to collapse everything into prices, the wage level rather than productivity is treated as the active determinant of labour market outcomes. Nonetheless, both marginal productivity and labour-power's price are treated as factors independent of agents on the demand side. Therefore, capital is removed from being responsible for wage and employment outcomes. That is, in the neoclassical account, an agent on the demand side is, quoting Adam Smith, "led by an invisible hand to promote an end which was no part of his intention"; or as in Marx's terminology, the 'bearer' of structural forces operating 'behind his back and beyond his will.

The passive price taking role assigned agents on the demand side in the formal orthodox theory contrasts starkly with the active responsibility for wage and (un)employment levels it assigns to supply side agents. Here, structural logic and the absence of choice (necessity) are neglected. Instead, (un)employment is always voluntary; the consequence of individual free choices. As the formal theory is widely presented, rather than to acquire the necessities of life, individuals only enter into work at the price they consider will compensate for leisure's loss. Leaving aside the ludicrous implication that everyone without work just sits around in a blissful state of leisure; the theory goes on to demonstrate that with free choice come consequences. That is, the higher the price required to tear individuals away from leisure; then the lower the demand for their paid employment. In short, while higher prices increase labour supply; they simultaneously reduce labour demand. Nonetheless, following Spencer (2006), if full employment is understood as 'work for everyone who wants it', then this is always present because (un)employment is voluntary such that low job availability due to high pricing is interpreted to mean that people don't really want to work.

Contained in the core of the orthodox account are seeds of the double-edged sword of the neoliberal discourse of 'individual responsibilisation' (Rose 1992). Individuals are free to be the architects of their own destiny (price setting), but they are responsible for and have to live with the consequences of their own free choices (job availability). Taken one step further, this free will argument enables the orthodox theory to be cast also as a parable of neoliberal morality. While the formal theory posits idleness as the natural human state, this unimproved human nature contrasts with the neoliberal crusade to promote the morality of working and the immorality of receiving rewards without working for them (Hackell 2013). In this light, employment levels ultimately reflect the aggregate morality. That is, employment levels increase the more people are willing and ready to work and without regard for reward; while 
employment levels reduce with increased work shyness and greed for greater reward. Thus, labour market outcomes vary according to the more or less moral behaviour of individuals. In sum, whatever the employment level is objectively, people as a consequence of their own voluntary agency do not simply get what they want, but more exactly, what they deserve! For the price-takers on the demand-side -without free will, without agency, and without moral responsibility for outcomes- political agency becomes about reforming the morality of the 'labouring population' in order to maximise the proportion willing to work at a lower price.

Keynes' approach offers significant departures from neoclassical orthodoxy. He argues that the spontaneous form of the market mechanism is not adequate to ensure that production levels for goods and services will correspond with full employment levels. In order for full employment to occur, production levels need to be increased by forms of state intervention that increase aggregate demand. This core analysis challenges the neoclassical claim that spontaneous markets including the labour market are stable, self-contained, or spontaneously tending towards equilibrium. Instead, Keynes' innovative account validates state-led counter-marketregulation designed to raise employment levels. His analysis not only validates regulation that can facilitate higher capital investment in production that increases employment, it also validates rising wages that increase production by increasing demand for goods and services. Thus, Keynesian analysis challenges sacred ideological cows of the orthodox perspective. It implies first, that there is something inherently wrong with unfettered markets, thus legitimating state-led counter-market regulation; that second, unemployment can be involuntary; and third, that increasing wages increases employment.

Though challenging key orthodoxies, the Keynesian approach remains grounded in the mainstream paradigm, and as such represents the key variation within an in-house debate. Obvious elephants in this house are invisibilized because they are external to the paradigm. In particular, absences in the mainstream paradigm stem from a lack of consideration of key paradigmatic elements of the Marxian perspective. In mainstream theory, there is just a historically dis-embodied market system; but no historically evolving 'mode of production'. 'Segmentation' of the 'labouring population' is absent, and instead there are only a-social individuals. The nature and implications of the power dynamics inherent to market relations cannot be examined because the market order is presented as power neutral. Connecting these invisible elephants in the mainstream's house is its short-run, one-dimensional focus on exchange relations, and its corresponding neglect of long-range structural logic based in production relations.

In the neoclassical perspective, production as a significant long-term causal factor in determining outcomes is methodologically factored out of the analysis. Capital investment in technology is treated only as one possible price-signalled short-term decision, rather than as a central element in the long term dynamic of increasing productivity under market relations. In the labour market account, (marginal) productivity is related only to individuals and not to the historical evolution of production systems. In Keynes' approach, focus is on short-run solutions to increase "aggregate demand" -for capital goods by reducing interest rates, and consumer goods by increasing wages- in order to promote increased production and thus employment. However, as the direct driver of unemployment almost nothing is made of problems with the historically evolving mode of production itself. 
In sum, neither approach has understood or considered capitalism as a historically evolving system of increasingly capital intensive production underpinned by capitalist social relations. Specifically, neither considers (un)employment implications of the empirical reality, that over real historical time to the present, the capitalist mode of production has generated indefinitely increasing productivity.

\section{Segmentation Theory, Marx and Generic Capitalism}

A $21^{\text {st }}$ century renewal of radical segmentation theory into the contemporary environment of 'neoliberal globalisation' not only involves its updating from the historical context of 1970s American Fordism. More basically, segmentation theory needs a stronger explanatory grounding; one which can be found in Marx's theory of the long-run dynamic of (un)employment under capitalism (Neilson and Stubbs 2011). Scattered in fragments across various publications, Marx outlines elements of a seminal long-range account of how capitalism's productivity drives labouring population's oversupply, defined as the 'relative surplus population', which underpins its segmentation (see especially Marx 1867 Ch. 25). In Marx's account the labouring population is as a result of this long term employment logic divided into three main, internally stratified, segments: the 'Relative Surplus Population': that first, is made surplus to a core productive workforce or 'Active Army': and second, from which is drawn a pool of irregularly employed but always ready and available for work: the 'Reserve Army of Labour'.

According to Marx's theory, increasing agricultural productivity underpinned by its industrialization dispossesses a large portion of the peasantry that becomes a surplus population who having lost their traditional means to live and with 'nothing to sell but their labour-power' seek employment in the cities. This process, repeated unevenly across national spaces and time to the present, is the first source of the 'modern proletariat' defined as those who "having no means of production themselves are reduced to selling their labour-power in order to live" (Marx and Engels 1952 40; quoted in Neilson 2007 89). Beyond this first relative surplus population, Marx's prognosis for capitalism's future history is continuing growth of the relative surplus population. This prognosis, according to Marx, is the ultimate historical endpoint of the basic logic and pattern of (un)employment that is underpinned by core capitalist social relations that drive indefinitely increasing productivity.

In Marx's account, in order to remain profitable, firms must at least match the changing product prices of competitors which require they produce at least at the value (labour-time expended in production) implied by existing wage and productivity norms, or what he defines as 'necessary labour'. Reducing necessary labour can be achieved by simply reducing wage levels but this has absolute limits. Over the long term, Marx argues that firm profitability is about being competitive with other firms as they struggle to match or surpass existing productivity norms which can reduce commodity values (including labour-power), and thus prices. Because profits are the source of investment in new technologies, price reductions without corresponding productivity increases will be unsustainable. Similarly, in order for investment in new technology to remain within profitability parameters requires that the labour-time expended in producing the new technology is less than the labour-time saved by its productive application.

This argument, in contrast with the technology-neutral mainstream neo-classical discourse, identifies a tendential structural logic that explains capitalism's consistent bias towards technology-driven increases in productivity. More significantly for the primary argument here 
about labour market segmentation, indefinitely increasing productivity literally means indefinitely reducing labour time as fewer workers are required to produce the same or greater quantity of products. Thus, Marx identifies a deep structural driver of unemployment that over the long term implies capital's declining demand for labour. Increasing productivity directly and literally 'throws workers on to the streets' who while there are a 'relative \{to the requirements of capital\} surplus population'. Rather than in a state of leisure, they are in deep precarity: unemployed and without the wages needed to purchase the necessities of life.

Of course there are important counter-tendencies. First, new technologies that can further increase productivity are a source of surplus labour's redeployment. However, as long as one assumes a positive difference between 'labour time invested' and 'labour-time saved' over the longer term, then this type of redeployment will intensify the central tendency of redundancy and over-supply. Second, the redundancy tendency is countered -in a way directly validating Keynesian policy to increase aggregate demand- by producing a greater volume (including variety) of goods. Over the long run, this second counter-tendency has seriously destabilising implications not noted by Marx. That is, at some indefinite temporal moment in this logic, the rate of material consumption required to increase production at a rate that equals the rate of redundancy of the labouring population will run up against ecologically sustainable limits. In sum, the basic long run tendency of this generic logic is to create a colliding trajectory between a growing 'relative surplus population' and deepening 'ecological un-sustainability' (see Neilson and Stubbs 2011). Catastrophic consequences are implied.

Contra mainstream theory, redundancy is a process by which people lose previous means of material existence, and thus while without work have no obvious way to live. Rather than being in a state of leisure; such people desperately seek employment in order to live. They enter into competition with each other to find jobs on the periphery of the Active Army or beyond. Contra the neoclassical argument that employers are price takers, this situation strongly favours the employer's capacity to command labour's price. That is, labour's oversupply increases competition amongst the labouring population for scarce jobs, which increases the power of capital to drive down the price of labour-power. In this theory, both capital and labour are constrained in their actions by their circumstances, but in this instance in a way that strongly favours the power of capital, while reducing to almost nothing the power of labour, to determine price outcomes. The neoclassical discourse reinforces this power by wilfully denying this reality.

In superficial consistency with neoclassical reasoning, however, lowered wages ceteris paribus can increase employment possibilities. First, reducing the price of labour-power increases the quantity and range of jobs that become viable within the marketplace. First, regarding quantity, if servants are paid $\$ 2.50$ an hour instead of $\$ 5.00$; members of the professional middle class segment of the Active Army may choose to employ two instead of one; and at that price lower paid but secure waged workers might be able to employ one instead of none. However, there is a floor to how low wages can go before they are insufficient to sustain life. No reason can be offered within the neoclassical paradigm, because the question cannot arise within it, to explain why full employment will be reached before such a point. Second, as the number of people desperate for work to live increases, so too does increase the number of people that in order to sustain life engage in forms of work not only at lower prices, but at lower qualities. Servant work, un-protected dangerous work, illegal work, prostitution, child labour, begging, stealing and worse, all increase. Furthermore, and contra neoclassical reasoning, because rewards are so low, individuals are compelled also to work longer hours. Thus, in this instance, supply increases 
with lower wages! However, neoclassical theory cannot consider these outcomes because employment is fancifully portrayed as a choice regardless of its quality and blind to its necessity.

Fundamentally, market logic superimposed on capitalism's long-term relative surplus population tendency drives increasing precarity for a growing proportion of the global labouring population. In this environment of an increasing relative surplus population, market logic systematically increases precarity: reducing rewards, work opportunities, quality of work, leisure time, and security.

\section{Constraints and Strategies under the Neoliberal Model of Development}

The original promise of the French Regulation School was to the fill the mid-range gap in Marx's theory of capitalism. I have attempted to revise regulation theory in ways that make it more able in particular to characterize not just the Fordist era, but also the current after-Fordist era as a 'model of development' (Neilson 2012). In a revision of the French Regulation School original meaning, I have argued that a 'model of development' is a mid-range trans-national regulatory project of which national states are integral elements, that has been intentionally designed and applied to facilitate a particular kind of capital accumulation and social reproduction. Models of development institutionally 'overdetermine' capitalism's generic relations and logic either towards their counter-active regulation or towards their pro-active regulation (see Neilson 2012; Neilson and Stubbs forthcoming).

The current neoliberal model of development, which as a practical blueprint crystallised in the 1980s under the Washington Consensus, has implemented a global market civilization vision centrally via a facilitating national template that since the 1980s has been widely implemented across the world's nation states. In a reversal of the Keynesian model, the neoliberal national template is all about deregulating trade and liberalizing finance in order to maximise national exposure to unimpeded capital flows (Gill 1995). This process, summarised in the term 'neoliberal globalization', has been about constructing, and now managing, extending and consolidating, the homogeneous space of unimpeded market imperatives and capitalist economic autonomy to a global scale. In short, the outcome of the neoliberal project's implementation has been to pro-activate generic capitalist logic globally. Thus, the terms of accumulation and employment for capital, labour, and nation states become increasingly defined by the globalisation of necessary labour. For a nation state to facilitate employment for its citizens it must be able to win the competition with other nation states to attract and keep mobile capital. In short, in order for a competition state to deliver national employment and prosperity, it must provide an institutional environment within which firms, across a sufficient number of fields and segments of a globally divided production process, can at least meet the global norms of necessary labour

Wage norms are driven down by labour's oversupply, and correspondingly capital's scarcity, which increase competition for scare jobs. In turn, the redundancy effects of increasing productivity, countered to an extent by the sale of a greater volume of goods, drives over the long-term labour's oversupply and capital's scarcity. Neoliberal globalisation pro-activates this generic long-term capitalist logic on a global scale. First, large-scale redundancy of the peasantry, creating a large relative surplus population coming from the countryside, has been driven by the imposing of global productivity norms on to previously protected and traditional forms of agricultural production (McMichael 2008). Also, the coercive effect of necessary labour's 
globalisation has been to also eliminate protected non-competitive industrial firms, implying Active Army redundancy (Neilson and Stubbs 2011). As forms of work that were previously protected are now suddenly subjected to the constraint of global norms, the inherent redundancy tendency is radically intensified as a massive one-off effect. However, as a result of the globalisation of necessary labour, redundancy tendencies within the core sectors of production are also increased.

In addition, and crucially for the Keynesian perspective, wages that are globally depressed by this oversupply are further depressed by the resulting reduction in aggregate demand. A relationship of 'competitive austerity' ensues, whereby countries constrain wages to attract capital, resulting in insufficient aggregate demand becoming an intractable problem the global level (Albo 1997). Adopting a 'Keynesianism in one country' approach, i.e. domestic demand-led growth based in wage increases, risks both a loss of nationally-located firm competitiveness and as well promotes price competitiveness of imported over export goods. This is not to say that a globally coordinated increase in wages across different nation states is not a viable Keynesian way to counter capitalism's productivity-driven redundancy tendency; but it is to demonstrate that without such trans-national coordination individual national initiatives are fraught (see Seo and Neilson 2014). To spell it out: as long as one assumes an environment of labour's oversupply on a global level, and a global market terrain that pits countries in competitive struggle against each other, then contra Keynesian theory, global wage norms will make it hard to avoid trade-offs at the national level between wage increases and jobs.

However, what might be called supply-side Keynesianism is a rational strategy for an advanced competition-state, and it challenges fundamental elements of the neoliberal national template. In particular, the close and active cooperation of state and organised labour to promote innovation and upskill the labouring population can increase national share of global production at the high-value end (Neilson and Stubbs forthcoming). Resulting increases in a nation state's global employment share of higher waged Active Army jobs will increase domestic demand, which will also encourage higher employment in the lower-paid service sector. In turn, this outcome will reduce welfare state costs and increase the state's tax revenue. With greater manoeuvrability, the state can increase the social wage, which increases domestic demand and further raises employment. However, for countries struggling to achieve competitiveness and worse, the logic operates in complete reverse, to intensify the deepening precarity of growing relative surplus populations.

If the national goal, in contest with other countries with the same goal, is to achieve full employment; then there is a strong case to be made that labour and nation states should focus on promoting productivity increases in cooperation with the needs of business. However, such national strategies, without basic changes to the neoliberal transnational framework, do not challenge the essential logic of neoliberal globalisation (Neilson and Stubbs forthcoming). That is, they do not change the contemporary competition state driven logic of uneven development, unleashed by the neoliberal model of development, which implies national winners and losers. Furthermore, the Keynesian project, first, only compensates for but does not directly challenge the long run subterranean logic of capitalism that makes workers redundant and, more disturbingly, second, by promoting increased production actually intensifies the tendency towards ecological over-reach. 


\section{Back to the Future: Beyond the Neoliberal Model of Development}

Progressively diverting the dangerous direction of contemporary neoliberal global capitalism requires more than competition-state Keynesianism. To achieve within the constraints of ecological sustainability secure income and working life quality for the world's labouring population, requires a new and innovative model of development (Neilson 2012, 2013; Neilson and Stubbs 2011, forthcoming). There are key lessons to be learned for the pursuit of such a project from the era of social progress that was made possible by the Fordist model of development, the blueprint of which was master-minded by Keynes; but there are also new challenges that need new elements incorporated into current neo-Keynesian thinking.

Achievements during the post WWII era of the Fordist model of development, the blueprint for which was negotiated at Bretton Woods in 1944, was above everything else driven by Keynes' vision of a transnational economic framework comprising a set of co-existing 'autocentric' national 'growth regimes', that gave room for countries to progressively counteract capital's coercive global logic (Neilson and Stubbs forthcoming). This formula contingently unfolded in as a negotiated macro-coordination of increasing productivity with wage driven rising consumption, in specifically varying national forms (Boyer 1988, 2005). Though compromised in various ways and structurally flawed, this temporary 'fix' underpinned nonetheless an exceptional era of 'social progress'.

By protecting and facilitating capitalism's viability at the national level, the Keynesian template tethered the vision of capital to a national stage. And, Keynesian domestic demand strategies facilitated a social democratic agenda grounded in the labour movement's pursuit of security, solidarity and rising living standards that was compatible with stable capital accumulation. In sum, the Fordist model of development delivered more or less across all advanced capitalist countries for 'about a generation' 'social progress' in the form of 'wage earner security': that included stable growth with high employment, rising living standards, low segmentation, reduced inequality, and an increased role for labour in the regulation of national economies (Aglietta 1998; Lipietz 1988; Standing 1997).

Future social progress is dependent on the framing of an alternative post-neoliberal model of development that can deliver a new transnational framework which will again make social progress viable at the national level. However, there is much work to be done to move progressive perspectives from the national to this trans-national stage. Further, while there are many lessons to be learned from a closer scrutiny of the Keynes-led Fordist model of development, there are also new and pressing challenges: especially about how to address the twin problems of the ecological unsustainability of continuing increases in production levels and the inter-linked problem of finding a way to deliver universal (not just for the advanced countries!) 'social progress'.

At the outset, the contemporary maximising of national exposure to global markets which makes local viability dependent on meeting capital's global norms needs to be redressed. Rather than subordinating nation states to the neoliberal project of a global market civilisation dominated by transnational capitalist interests; a global vision needs to be developed that prioritises 'social progress' grounded first and foremost in universal economic (and thus integrally including ecological) viability at local/national levels. 
Within this new vision, specific focus needs to be placed on consciously promoting the development of local (socially and ecologically progressive) alternatives to the currently existing networked global production of agricultural and industrial goods (see Neilson 2013). Practical achievement of such radical departures from existing forms of global production would require key developments at the level of a new transnational framework, centrally including the establishing of a mode of regulated competition coordinated at the global level. Rather than structurally favouring global scale, uneven development across nation states, and a 'wage race to the bottom' a globally regulated mode of competition is required that would focus on competition between firms to sell knowledge to a world knowledge bank and practical expertise at local levels. Such knowledge and expertise would prioritise the pursuit of ecologically sound, socially progressive, and locally self-contained forms of production.

Freed from the coercive constraints of globalised necessary labour, and supported by globalised knowledge and resources dedicated to achieving localised food sovereignty and manufacturing diversity for all countries; work and employment could be organised according to democratically negotiated local priorities. In this environment there can really be 'social progress' grounded in decent work for everyone who wants it, combined with a universal basic income derived material security for all. In sum, neoliberal globalisation needs to be reversed and replaced with an ecologically updated 'social democratic glocalisation'.

\section{Conclusion}

Keynesian thinking, while challenging key aspects of neoclassical labour market theory, remains limited by its mainstream paradigmatic location. An updated neo-Marxist approach with no such limitation is able to throw light on mainstream short run analysis of market logics by bringing in a long range production theory based account. Moreover, this paper has ended up trying to draw Keynesianism away from its mainstream integument and towards its further radicalization both by bringing in neo-Marxist insights, and by more clearly focusing both approaches on constructing the urgently-needed blueprint for a new model of development beyond neoliberal globalisation.

Neo-classical labour market theory crudely assigns agency to labour in a way that both responsibilizes it and diverts attention away from the flawed character of capitalism and its powerful agents. In contrast, this analysis demonstrates the structural constraints of action under capitalism for labour and nation states as well as capital; but at the same time, draws our attention to agency as praxis that underpins regulatory projects to reshape the world.

\section{References}

Aglietta, M. (1998). Towards a new regime of growth. New Left Review, 232, 41-90.

Albo, G. (1997). A world market of opportunities? Capitalist obstacles and left economic policy. In Panitch, L. (1997.) (ed.) The Socialist Register. London, Merlin.

Boyer, R. (1988). Wage/labour relations, growth, and crisis: A hidden dialectic. In Boyer, R. (ed.) The Search for Labour Market Flexibility. Oxford: Clarendon Press. 
Boyer, R. (2005). How and why capitalisms differ. Economy and Society, 34, 4, 509-57.

Gill, S. (1995). Globalization, market civilization and disciplinary neoliberalism. Millennium, 24, 3, 399- 423.

Hackell, M. (2013). Taxpayer citizenship and neoliberal hegemony in New Zealand. Journal of Political Ideologies, 18, 2, 129-149.

Lipietz, A. (1988). Reflections on a tale: The Marxist foundations of the concepts of regulation and political economy. Studies in Political Economy, 26, Summer, 7-35.

McMichael, P. (2008). Peasants make their own history, but not just as they please. Journal of Agrarian Change, 8, 2-3, 205-228.

Marx, K. (1976). [1867]. Capital: Vol. 1. Introduced by Ernest Mandel. Translated by Ben Fowkes. Harmondsworth: Penguin in association with New Left Books.

Marx, K. and Engels, F. (1952). [1848]. The Communist Manifesto. Moscow: Progress.

Neilson, D. (2007). Formal and real subordination and the contemporary proletariat: Recoupling Marxist class theory and labour process analysis. Capital \& Class, 91, 89-123.

Neilson, D. (2012). Remaking the connections: Marxism and the French Regulation School. Review of Radical Political Economics, 44, 2, 160-177.

Neilson, D. (2013). Reworking the scientific socialist prognosis in the $21^{\text {st }}$ century: Mid-Range contingency and a counter-hegemonic model of development, Knowledge Cultures, 1, 2, 73 93.

Neilson, D. and Stubbs, T. (2011). Relative surplus population and uneven development in the neoliberal era: theory and empirical application. Capital \& Class, 35, 3, 435-453.

Neilson, D and Stubbs, T. (forthcoming). Competition states in the neoliberal Era; Beyond the varieties of capitalism approach towards third generation regulation theory. Competition \& Change.

Seo, H. J. and Neilson, D. (2014). From the global financial crisis to global Keynesian new deal: For the success of a modern version of wage-led growth strategy. The Review of Social and Economic Studies, 43, 2, 139-180.

Spencer, D. (2006). Work for all those who want it? Why the neoclassical labour supply curve is an inappropriate foundation for the theory of employment and unemployment. Cambridge Journal of Economics, 30, 459-472.

Standing, G. (1997). Globalization, labour flexibility and insecurity: The era of market regulation. European Journal of Industrial Relations, 3, 1, 7-37. 
Rose, N. (1992). Governing the enterprising self. In Heelas and Morris (eds), (1992). The Values of the Enterprise Culture. 